\title{
General Haigs tannpine
}

Under den første verdenskrig forekom det et stort antall kjeve- og ansiktsskader som sanitetspersonellet innledningsvis ikke var tilstrekkelig kvalifisert for å behandle. I denne situasjonen synes en rekke tilfeldigheter å ha ledet til utviklingen av to kirurgiske subspesialiteter: kjevekirurgi og plastikkirurgi.

Skuddene i Sarajevo sommeren 1914 utløste den første verdenskrig, og europeiske stormakter avga krigserklæringer på ettersommeren. 4. august erklærte England krig mot Tyskland, og British Expeditionary Force ble overført til Frankrike. Feltmarskalk sir John French (1852-1925) var øverstkommanderende fra begynnelsen. French fratrådte fra årsskiftet 1914/15 og ble etterfulgt av general Sir Douglas Haig (1861-1928) (fig 1) som ble utnevnt til feltmarskalk (1). Haig fikk sterk tannpine og behov for profesjonell hjelp. Ingen tannleger var tilknyttet British Expeditionary Force, og tannleger ble rangert lavere enn veterinærer og grovsmeder for innsats i hæren (2). Haig måtte derfor fraktes til Paris der han ble behandlet av den fransk-amerikanske tannlegen Auguste Charles Valadier (1873-1931). Han var utdannet fra Philadelphia Dental College i 1901 og praktiserte i New York frem til 1910 da han returnerte til sitt fødeland og Paris.

\section{Valadier}

Kjeve- og ansiktsskader forekom i stort antall under verdenskrigen (3), og etter krigsutbruddet var Valadier interessert i å bidra med sine kvalifikasjoner. Han kunne knapt ha ønsket seg en mer velegnet pasient å drøfte dette med enn generalen. Detaljer fra møtet er ikke kjent, men forhåpentlig ble generalen kurert for sin tannpine, og møtet førte kanskje til at det ble fattet viktige beslutninger. Haig beordret tannleger til British Expeditionary Force, og senhøsten 1914 var 11 «dental surgeons» ankommet. Valadier meldte seg til innsats for britisk Røde Kors i Paris, og ble på honorær basis engasjert til tjeneste i den engelske hær fra oktober 1914, som den første og eneste tannlege. Valadier ble plassert ved 83. hospital i den lille byen Wimereux nær Boulogne-sur-Mer, der han organiserte en 50-sengers enhet for behandling av kjeve- og ansiktsskader. Han arbeidet innledningsvis under frie tøyler, anskaffet utstyr for egne midler og samarbeidet med sin egen tannteknikerstab i Paris for fremstilling av spesialutstyr for behandling av kjeveskader. Det ble imidlertid bestemt fra sentralt kommandohold at Valadier ikke skulle operere selvstendig, men samarbeide med «a medical man». I denne rollen ble øre-nese-hals-lege Harold Gillies

(1882-1960) sendt til Wimereux (4).

\section{Gillies}

Gillies ankom Wimereux tidlig på nyåret 1915 og innledet samarbeidet med Valadier. Han fikk demonstrert avanserte tekniske metoder som Valadier hadde utviklet for behandling av kjeveskader, og ble sterkt inspirert av denne nye kirurgiske subspesialiteten. Stort sett ble det ved bataljonshjelpeplasser kun foretatt hemostase og bløtvevssutur. Blodtransfusjon kunne ikke utføres, og infeksjonsfaren var overhengende. Gillies innså at kjevekirurgi og plastikkirurgi var nødvendige og høyverdige spesialområder innen krigskirurgi. Med denne erkjennelse reiste han tilbake til England, der han overtalte hærens sjeflege til å innrette en egen avdeling for ansiktsskader i Cambridge Military Hospital i Aldershot (4). Dette ble en milepæl i historien om introduksjon av to nye spesialiteter i krigskirurgien. Spesialavdelingen ble i 1917 flyttet til det nyetablerte Queen Mary's Hospital nordvest i London. Her ble mer enn 5000 soldater operert for maxillofaciale skader, og Gillies og medarbeidere utviklet avanserte plastikkirurgiske metoder, bl.a. hudtransplantasjon. Gillies' pionervirksomhet innledet utvikling av plastikkirurgi i USA, Frankrike, og etter hvert flere steder i Europa (5).

I løpet av 1918 ble virksomheten i Wimereux sterkt redusert, og sykehuset fikk etter hvert funksjon som en «clearing station» før evakuering til Queen Mary’s Hospital i London og Harold Gillies' team. Gillies verdsatte Valadiers pionerinnsats høyt, som det fremkommer i følgende uformelle hyllest: "In Boulogne there was a great fat man with sandy hair and a florid face. The name of this man whose high brown riding boots carried a polish equal to the glitter of his spurs was Charles Valadier. With the Generals strapped in his chair, he convinced them of the need of a plastic-and jaw unit, and one was set up nearby in the lovely little town of Wimereux. I was invited by Valadier to accompany him to assist in his initial incision... The credit for establishing the first Plastic-and Jaw Unit, which so facilitated the later progress of plastic surgery, must go to the remarkable linguistic talents of the smooth and genial Sir Charles Valadier» (4).

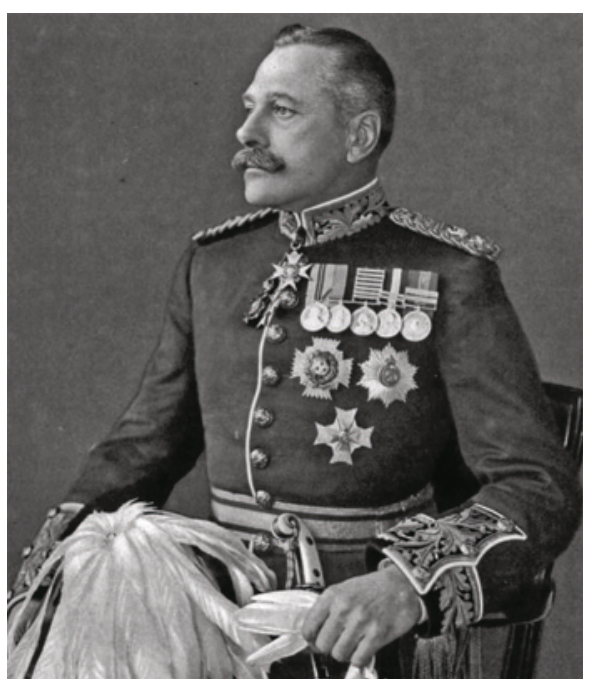

Figur 1 Sjefen for British Expeditionary Force i Frankrike 1915-18, feltmarskalk Douglas Haig (1861-1928). Foto: Wikipedia commons

Etter krigen vendte Valadier tilbake til sin praksis i Paris, der han også bedrev kjevekirurgi. Han mottok den franske Æreslegionen i 1919 og ble adlet i 1921. Hans siste fem leveår var preget av en blodsykdom, trolig leukemi, og han døde i 1931 (4).

\section{Jacob M. Klafstad}

jklaf@broadpark.no

Jacob M. Klafstad (f. 1934) er lege og tannlege. pensjonert spesialist i maxillofacial kirurgi og tidligere medisinsk hovedlærer ved Våpenskolen for Hærens sanitet samt stabslege for Sjøforsvaret.

Forfatter har fylt ut ICMJE-skjemaet og oppgir ingen interessekonflikter.

\section{Litteratur}

1. Churchill W. Verdenskrigens historie «The Great War». Oslo: Cappelen, 1935

2. Palmer P. Haigs toothache - Dentistry in the BEF 1914-1918. www.westernfrontassociation.com/ great-war-on-land/casualties-medcal/1037haigs-toothache-dentistry-bef-1914-18.html (2.5.2014).

3. Klafstad J. Krigssanitet, en retrospektiv og prospektiv studie av landkrigens sanitet. Oslo: Norsk Militært Tidsskrift, 1985.

4. McAuley JE. Charles Valadier: a forgotten pioneer in the treatment of jaw injuries. Proc R Soc Med 1974; 67: 785-9.

5. Rowe NL, Killey HC. Fractures of the facial skeleton. London: E \& S Livingstone, 1955. 